\title{
MENJADI ISLAM SAMA DENGAN MENJADI MISKIN1 \\ (Studi Adaptasi Muallaf Tionghoa Terhadap Masyarakat Aceh)
}

\section{Triyanto}

Dosen Tetap Jurusan Sosiologi Fisip Universitas Teuku Umar Meulaboh Email: triyanto3222@gmail.com

\begin{abstract}
Muallaf life of Chinese Crossbreed community in Aceh Barat is not as good as with other crossbreed. Muallaf were expelled from their family, even business relationships between the members of the ethnic Chinese crossbreed also cut off so economically bankrupt and ended up living in poverty. Because of this, part of other ethnic Chinese who wants to convert to Islam with fear and cancel his intention. The emergence of the phrase "to be Islam is synonymous with being poor" because of poverty muallaf occurred since left the business relationship that has been built, and also expelled from their family, so that the financial assistance from the family when someone needs also suspended. One thing that makes business relations and expulsion of muallaf family leave because they have left ("betray") and their ethnic ancestry. Meanwhile, in the face of poverty, some of them were forced to leave Meulaboh city and live in Banda Aceh or Medan. It is not exactly known how the living conditions of ethnic Chinese crossbreed muallaf of Meulaboh in those cities. While others choose to stay in Meulaboh and live in simple life. To finance his family life, muallaf are working as parking attendants, bookselling, garbage collectors and scavengers, caring for and maintaining the child, as well as working as a factory worker. However, the simple and poor life would be rewarded with good, because it reverts Chinese crossbreed people can live together with Acehnese people. In the belief that a new life as a new muallaf will receive a trial from God. For that, there is only one strong determination to survive as a muallaf despite poor living up to his death, and the Lord called him in eternity.
\end{abstract}

Keywords: adaptation, poverty, convert, Chinese, Meulaboh, Peranakan.

1 Judul ini pengembangan dari Tesis Penulis berjudul Dakwah Islam pada Komunitas Tionghoa (Studi Tentang Adaptasi Dengan Masyarakat di Meulaboh Kabupaten Aceh Barat). UIN Arraniry. Banda Aceh. 


\section{PENDAHULUAN}

Hampir di setiap kota selalu tampak eksistensi orang-orang peranakan Tionghoa, atau secara awam sering disebut sebagai orang China. Keberadaan peranakan Tionghoa selalu dikenal sebagai orang yang kaya raya yang memiliki perusahaan banyak, hidup mewah dan serba kecukupan. Bahkan di beberapa kota peranakan Tionghoa tampak tinggal di perumahan-perumahan elit dan khusus. Bukan hanya itu, etnis ini yang usia anak-anak juga bersekolah di sekolah-sekolah berkelas dan mahal, baik itu di tingkat TK, SD, bahkan sampai perguruan tinggi.

Peranakan etnis Tionghoa di Kota Meulaboh Kabupaten Aceh Barat, kebanyakan memiliki kondisi yang sama dengan kota-kota lainnya. Peranakan etnis Tionghoa hidup di daerah tertentu, sebagai seorang pedagang atau pengusaha sukses yang kaya dan hidup mewah, serta mendominasi perdagangan. Triyanto mengatakan bahwa peranakan etnis Tionghoa menurut tempat tinggalnya terbagi dalam dua kategori. Pertama, tinggal di kota dan kedua, tinggal di gampoeng-gampoeng sekitar kota. ${ }^{2}$

Peranakan etnis Tionghoa yang tinggal di kota terkesan eksklusif seolah tidak berbaur dengan masyarakat selain dari peranakan. Dalam amatan, peranakan etnis Tionghoa juga berbaur dengan etnis Aceh atau etnis lainnya yang tinggal di Meulaboh, namun terbatas pada orang-orang yang berhubungan seperti para pelanggan, kawan sekolah, atau orang yang menjadi pekerjanya saja. Terbatasnya interaksi antara peranakan etnis Tionghoa dengan orang Aceh disebabkan pada budaya yang berbeda. A. Rani menunjukkan terbatasnya interaksi antara peranakan etnis Tionghoa dengan etnis Aceh lebih disebabkan karena kecintaan peranakan Tionghoa dengan tanah leluhur dan nenek moyangnya. ${ }^{3}$ Dengan kuatnya hubungan emosional tersebut peranakan etnis Tionghoa menjadi sulit untuk melebur dengan orang Aceh, sehingga masyarakat umum memiliki persepsi berbeda dan menyebutnya sebagai kelompok kelas atas.

Kehidupan yang tampak glamour, kelas atas, dan selalu sukses dalam menjalankan bisnis merupakan pandangan bangsa Indonesia dari etnis lainnya saat melihat masyarakat peranakan etnis Tionghoa. Orang Aceh juga memandang bahwa peranakan etnis Tionghoa hidupnya jauh dari kemiskinan, kesengsaraan dan kenistaan, padahal semua itu tidak benar. ${ }^{4}$ Arman dalam Suhandinata juga mengatakan "Etnis Tionghoa tinggal di daerah yang mewah dan ekslusif di kota-kota

${ }^{2}$ Mengenai tempat tinggal peranakan etnis Tionghoa, Triyanto membagi ke dalam dua tempat, dimana peranakan etnis Tionghoa yang tinggal di kota yang mewakili para pengusaha atau pedagang, sedangkan yang tinggal di tempat kedua yakni di gampoeng-gampoeng satelit mewakili peranakan etnis Tionghoa sebagai pekerja. Di Kota Meulaboh banyak tinggal khususnya di jalan Singgahmata, Jalan Nasional, Jalan Teuku Umar, dan beberapa tempat lainnya tetapi hanya sedikit. Sedangkan di gampoeng-gampoeng satelit khususnya di Rundeng, Seunebok, Gampa, dan Lapang.

${ }^{3}$ A. Rani Usman. 2009. Etnis Cina Perantauan di Aceh. Yayasan Obor Indonesia. Jakarta. Hal. 252.

4 Triyanto. Dakwah Islam pada Komunitas Tionghoa (Studi Tentang Adaptasi Dengan Masyarakat di Meulaboh Kabupaten Aceh Barat). Banda Aceh: UIN Ar-raniry. 2014. Hal. 124 
besar dan tidak suka bersosialisasi dengan masyarakat sekitarnya yang umumnya miskin dan sangat pas-pasan untuk menyambung hidup" ${ }^{5}$

Kenyataannya ada beberapa peranakan etnis Tionghoa yang kondisi ekonominya jauh dari kata sejahtera, apalagi kaya dan hidup bermewah-mewahan. Kelompok kedua dari klasifikasi Triyanto yakni yang tinggal di gampoeng-gampoeng sekitar kota, ternyata merupakan peranakan etnis Tionghoa yang bukan pedagang atau pengusaha, melainkan sebagai pekerja yang mendapat upah dari atasannya. Sebagian lagi, memiliki penghidupan yang jauh lebih buruk. Hal menarik adalah kebanyakan peranakan etnis Tionghoa yang tinggal di pinggiran kota tersebut merupakan peranakan yang menjadi muallaf, atau memeluk Agama Islam. Artinya, yang tinggal di pinggiran dan menjadi muallaf ini dapat dikatakan memiliki kehidupan yang lebih buruk daripada peranakan yang tinggal di kota yang masih memegang kebudayaan nenek moyangnya. Sehingga ada sebuah ungkapan "Menjadi Islam sama dengan menjadi miskin".

Masyarakat Aceh dari etnis non peranakan Tionghoa yang sudah memeluk Agama Islam lebih dahulu, tidak semua miskin. Banyak yang memiliki kehidupan yang sejahtera ${ }^{6}$, bahkan subetnis Aceh yang merupakan pendatang juga banyak yang hidup sejahtera. Melihat kenyataan ini, orang Islam sebenarnya juga mampu untuk hidup sejahtera, kaya bahkan hidup bermewah-mewah lalu bagaimana munculnya ungkapan menjadi Islam sama dengan menjadi miskin di kalangan muallaf peranakan etnis Tionghoa? Kemudian bagaimana muallaf peranakan etnis Tionghoa menghadapi kemiskinannya dalam kehidupan sehari-hari? Dua permasalahan ini perlu mendapatkan penjelasan yang realistis empiris dalam kajian sosiologis.

\section{Tinjauan Pustaka}

Kajian tentang peranakan etnis Tionghoa di Meulaboh pada saat ini belum begitu banyak, khususnya komunitas yang beragama islam. Peranakan etnis Tionghoa yang telah beragama islam ini tidak tampak mencolok di muka umum. Bahkan hanya beberapa orang saja yang dapat mengenali komunitas ini, terutama anggota ikatan keluarga muallaf (IKM) dari berbagai etnis yang ada di Meulaboh, dan juga anggota

5 Justian Suhandinata, WNI Keturunan Tionghoa dalam Stabilitas Ekonomi \& Politik Inndonesia, Jakarta: Gramedia Pustaka Utama, 2009. Hal. 317.

6 Sejahtera menurut Nugroho seperti dikutip Saragih sekurang-kurangnya dapat memenuhi indikator sebagai berikut; 1) Lantai bangunan (rumah) bukan dari tanah/bambu/kayu murahan. Banyak masyarakat Aceh atau sub etnis Aceh yang memiliki rumah dengan lantai dikeramik atau sekurang-kurangnya dibuat dari semen/diplester. 2) Dinding tempat tinggal bukan terbuat dari bambu/rumbia/kayu berkualitas rendah/tembok tidak diplester. 3). Masing-masing tempat tinggal memiliki fasilitas buang air besar (WC). 4). Semua rumah di Meulaboh dan sekitarnya menggunakan penerangan listrik. 5). Bahan bakar untuk memasak sehari-hari menggunakan gas. 6). Hampir semua sanggup makan tiga kali dalam sehari. Ada beberapa hal lagi yang menjadi indikator kesejahteraan menurut Nugroho yang dikutip saragih, namun setidaknya 6 (enam) poin di atas secara jelas dapat dipenuhi hampir semua masyarakat. (Irma saragih. Analisis Dampak Program Raskin Terhadap Kesejahteraan Rumah Tangga Miskin: Studi Kasus di Gampong Ujong Tanoh Darat Kecamatan Meurebo Kabupaten Aceh Barat. Prodi Administrasi Negara Fisip Universitas Teuku Umar Meulaboh. 2013. Hal. 17-18). 
Persatuan Islam Tionghoa Indonesia (PITI) Aceh Barat yang anggotanya telah melebur ke dalam IKM.

Dalam lingkup Provinsi Aceh, kajian tentang peranakan etnis Tionghoa telah dilakukan beberapa peneliti dari perguruan tinggi. A. Rani Usman dari UIN Ar-raniry Banda Aceh, mengkaji peranakan etnis Tionghoa yang berada di Kota Banda Aceh. A. Rani Usman bahkan menerbitkan kajian tersebut dengan judul Etnis Cina Perantauan di Aceh. Dalam kajiannya A. Rani Usman memfokuskan pada bagaimana membangun komunikasi antar budaya. A. Rani Usman melihat adanya stereotype kehidupan orang Cina (baca peranakan etnis Tionghoa) di Indonesia, yakni orang Cina dapat hidup harmonis dengan penduduk lokal, namun pada sisi lainnya atau saat tertentu terjadi konflik. ${ }^{7}$ Dikatakan harmonis karena A. Rani melihat kenyataannya, bahwa orang Cina yang ada di seluruh Indonesia khususnya di Banda Aceh dapat bertahan hidup dan berkembang seperti etnis lainnya. Bahkan juga menjalin hubungan yang baik dengan masyarakat selain dari etnisnya sendiri, meskipun diantaranya hanya sebatas hubungan dengan pelanggan atau semua yang memiliki hubungan bisnis. Sisi konfliknya dapat dilihat dalam catatan kelam sejarah bangsa Indonesia.

Hasil kajian A. Rani seperti dikutip Triyanto menunjukkan bahwa interaksi dan komunikasi antara orang Tionghoa dengan orang Aceh terjadi melalui pola pemukiman, pendidikan, bisnis, kegiatan sosial, dan hubungan antara karyawan dan pimpinan. ${ }^{8}$ Triyanto sendiri tidak mengkaji interaksi peranakan etnis Tionghoa yang ada pada pendidikan di Meulaboh Aceh Barat, meskipun ada juga beberapa peranakan etnis Tionghoa usia sekolah yang bersekolah di sekolah negeri, namun itu tidak banyak. Bahkan dalam wawancara seorang informan menyatakan bahwa kebanyakan peranakan etnis Tionghoa bersekolah di tempat-tempat atau sekolah yang menunjukkan eksistensi komunitasnya.

Kajian peranakan etnis Tionghoa di Aceh lainnya juga dilakukan oleh Wildan dkk yang memfokuskan pada bahasa yang dikuasai oleh peranakan etnis Tionghoa di Aceh. Hasil penelitiannya menunjukkan bahwa peranakan etnis Tionghoa yang ada di Aceh menguasai berbagai macam bahasa, dalam kajian Triyanto Wildan mengatakan bahwa masyarakat Tionghoa di Aceh ternyata banyak menguasai bahasa, diantaranya: bahasa Tionghoa, bahasa Indonesia, bahasa Aceh, bahasa Jamee, bahasa Gayo, bahasa Jawa, bahasa Sunda, bahasa Batak, bahasa Jepang, bahasa Korea dan bahkan bahasa Arab. ${ }^{9}$

Kajian peranakan etnis Tionghoa di Aceh juga dilakukan Triyanto (2014) dengan judul dakwah Islam pada Komunitas Tionghoa; studi tentang adaptasi dengan masyarakat di Meulaboh Kabupaten Aceh Barat. Hasil penelitiannya menunjukkan bahwa kesadaran setiap individu memerlukan orang lain, sementara itu peranakan etnis Tionghoa juga menyadari adanya perbedaan adat-istiadat, nilai-nilai yang berlaku dalam masyarakat, norma-norma. Untuk itu komunitas peranakan etnis Tionghoa muallaf perlu mempelajari dan melakukan sosialisasi ulang dengan masyarakat Aceh. Pada sisi yang lain muallaf peranakan etnis Tionghoa juga menjalin hubungan dengan keluarga besarnya, meskipun mendapatkan perlakuan yang kurang menyenangkan.

\footnotetext{
7 A. Rani Usman. Etnis Cina Perantauan ....... Hal. 1

${ }^{8}$ Triyanto. Dakwah Islam Pada Komunitas Tionghoa.........hal. 9

${ }^{9}$ Triyanto. Dakwah Islam Pada Komunitas Tionghoa..........hal. 10
} 


\section{Temuan dan Pembahasan}

Peranakan etnis Tionghoa di berbagai daerah telah berusaha untuk mendapatkan statusnya sebagai warga negara Indonesia yang berstatus pribumi. Kenyataannya status pribumi tidak mudah didapatkan, secara administrasi kependudukan bukan hal sulit untuk mendapatkan, namun juga bukan hal mudah untuk mendapat pengakuan dari masyarakat. Hal ini sangat berbeda dengan orang peranakan etnis India dan Arab yang ada di Indonesia. Warman dalam Suhandinata yang dikutip Triyanto mengatakan bahwa orang India dan Arab mudah diterima di Indonesia karena budaya India dan Arab lebih dikenali dibandingkan dengan budaya Tionghoa. ${ }^{10}$

Dalam penjelasan Suhandinata mengatakan bahwa orang Indonesia sangat familiar dengan budaya India yang diwarnai dengan budaya Hindu. Hal ini menjadi mudah dimengerti karena masyarakat Indonesia sebelum memeluk Agama Islam merupakan penganut Agama Hindu. Dengan demikian, budaya Hindu yang diwariskan kepada masyarakat Indonesia sekarang dan sebagian masih dilakukan, atau terjadi akulturasi dengan Islam sangat mudah dipahami. Hal serupa dengan orang Arab, dimana budaya Arab sangat dipahami orang Indonesia, terlebih lagi saat ini Islam yang bermula dari Arab menjadi agama mayoritas, tentu sangat dikenali bahkan beberapa justeru mendapat penghormatan tersendiri. Hal ini sangat jauh berbeda dengan peranakan etnis Tionghoa yang sulit dipahami orang Indonesia.

\section{Munculnya Ungkapan Menjadi Islam Sama Dengan Menjadi Miskin}

Beberapa orang dari peranakan etnis Tionghoa telah menjadi muallaf atau telah memeluk agama Islam. Namun memiliki keyakinan baru, ini akan dianggap meninggalkan budaya nenek moyangnya, bahkan sebagian menyebut sebagai mengkhianati nenek moyangnya. Menjadi muallaf dan dianggap meninggalkan keyakinan serta budaya nenek moyangnya ternyata membawa dampak yang sangat buruk dalam kehidupannya. Setelah memeluk agama Islam, muallaf peranakan etnis Tionghoa ini diusir dari rumah, bahkan sejumlah relasi bisnis meninggalkan dan memutuskan hubungan, sehingga usahanya menjadi bangkrut. Hasil penelitian Dhea seperti dikutip Triyanto mengatakan “...peranakan etnis Tionghoa yang menjadi muallaf diusir dari keluarga". 11

Hasil penelitian Dhea juga terjadi di Kota Meulaboh, peranakan etnis Tionghoa yang memeluk agama Islam diusir dari keluarganya. Hasil wawancara dengan beberapa muallaf peranakan etnis Tionghoa menunjukkan bahwa terjadi pengusiran dari keluarga terhadap muallaf. Bahkan muallaf yang tidak berani keluar dari keluarga terpaksa harus ribut dengan keluarga. Bukan hanya sekedar ribut, pada akhirnya muallaf ini terpaksa harus menyerah dan kembali ke agama keluarganya. Tidak meninggalkan kebudayaan keluarga dan nenek moyangnya yang berbeda dengan kebudayaan "pribumi" 12 yang mayoritas Islam.

10 Triyanto. Dakwah Islam Pada Komunitas Tionghoa. hal. 126-127

${ }^{11}$ Triyanto. Dakwah Islam Pada Komunitas Tionghoa.........hal. 86

12 Istilah pribumi dan non pribumi sudah mulai ditinggalkan dalam kajian peranakan etnis Tionghoa. Hal ini berdasarkan instruksi presiden nomor 26 tahun 1998 tentang penghentian penggunaan istilah pribumi dan non pribumi. 
Menurut Kok Eyuk Wun dan Iechien Mei beberapa peranakan etnis Tionghoa yang sudah meninggalkan keluarganya juga terpaksa meninggalkan Kota Meulaboh. Menjalani hidup di Meulaboh cukup berat bagi mereka. Secara jelas Kok Eyuk Wun mengatakan:

"Beberapa muallaf Tionghoa di Meulaboh ini terpaksa berpindah ke Medan dan Banda Aceh. Saya tidak tahu mereka di sana apakah kembali ke agama semula atau tetap bertahan sebagai seorang muslim, karena hidup di Meulaboh tidak ada orang China yang mau bekerjasama dengannya. Kita tahu sendiri orang China pekerjaannya ya hanya berdagang, tidak ada yang bekerja selain dagang. Hanya sedikit orang China yang kerja sebagai buruh di sini, seperti tukang sampah, tukang parkir, dan pekerja kasar lainnya. Itu pun yang telah masuk Islam, yang tidak Islam semua pedagang".

Kok Eyuk Wun memandang perlu adanya informasi lebih lanjut mengenai keberadaan peranakan etnis Tionghoa di Banda Aceh dan Meulaboh yang berasal dari Meulaboh. Selama ini sebagai mantan ketua PITI Aceh Barat merasa kehilangan kontak dengan anggotanya yang telah meninggalkan Meulaboh. Kok Eyuk Wun khawatir mantan anggotanya itu telah kembali ke agama semula, karena tidak mudah hidup menjadi muallaf Tionghoa. Kerasnya kehidupan menuntut anggotanya untuk tetap hidup, sedangkan tidak ada peranakan etnis Tionghoa yang mau bekerjasama dengannya untuk berbisnis dan menghasilkan uang. Sebagai etnis peranakan, juga sulit mendapatkan akses kerjasama atau bekerja kepada masyarakat lokal. Masyarakat Aceh atau masyarakat non peranakan etnis Tionghoa dimanapun juga sulit menerima peranakan ini untuk bekerja di toko atau perusahaan, bahkan kantor tempatnya bekerja. Kalau pun ada hanya beberapa orang dan itu sangat sulit ditemukan.

Bukan hanya berhenti pada hilangnya relasi bisnis, dihentikannya keuangan keluarga, dan sulitnya mendapatkan pekerjaan, tetapi juga ucapan sinis dari sebagian masyarakat Aceh. Kok Eyuk Wun mengatakan "Lihat orang itu, ketika sudah miskin baru masuk Islam". ${ }^{13}$ Kondisi seperti ini membuat mantan ketua PITI Meulaboh itu sedih dan menyayangkan ucapan beberapa masyarakat Aceh yang sudah Islam lebih dahulu. Seharusnya sebagai orang Islam, bagaimanapun harus tetap baik dan jauhjauh menghilangkan pemikiran buruknya mengenai muallaf peranakan etnis Tionghoa. Dalam pandangan Kok Eyuk Wun, kemiskinan yang dialami muallaf peranakan etnis Tionghoa karena meninggalkan keyakinan lamanya dan memilih untuk menjadi seorang muslim, yang berakibat hilangnya hubungan bisnis, dikeluarkan dari keluarga, kehilangan mata pencaharian, dan jatuh miskin. "Jadi menjadi muslim bukan setelah miskin", kata Kok Eyuk Wun. Kondisi tersebut jika digambarkan dalam sebuah model terlihat seperti gambar berikut:

\footnotetext{
${ }^{13}$ Triyanto. Dakwah Islam Pada Komunitas Tionghoa..........hal. 86
} 


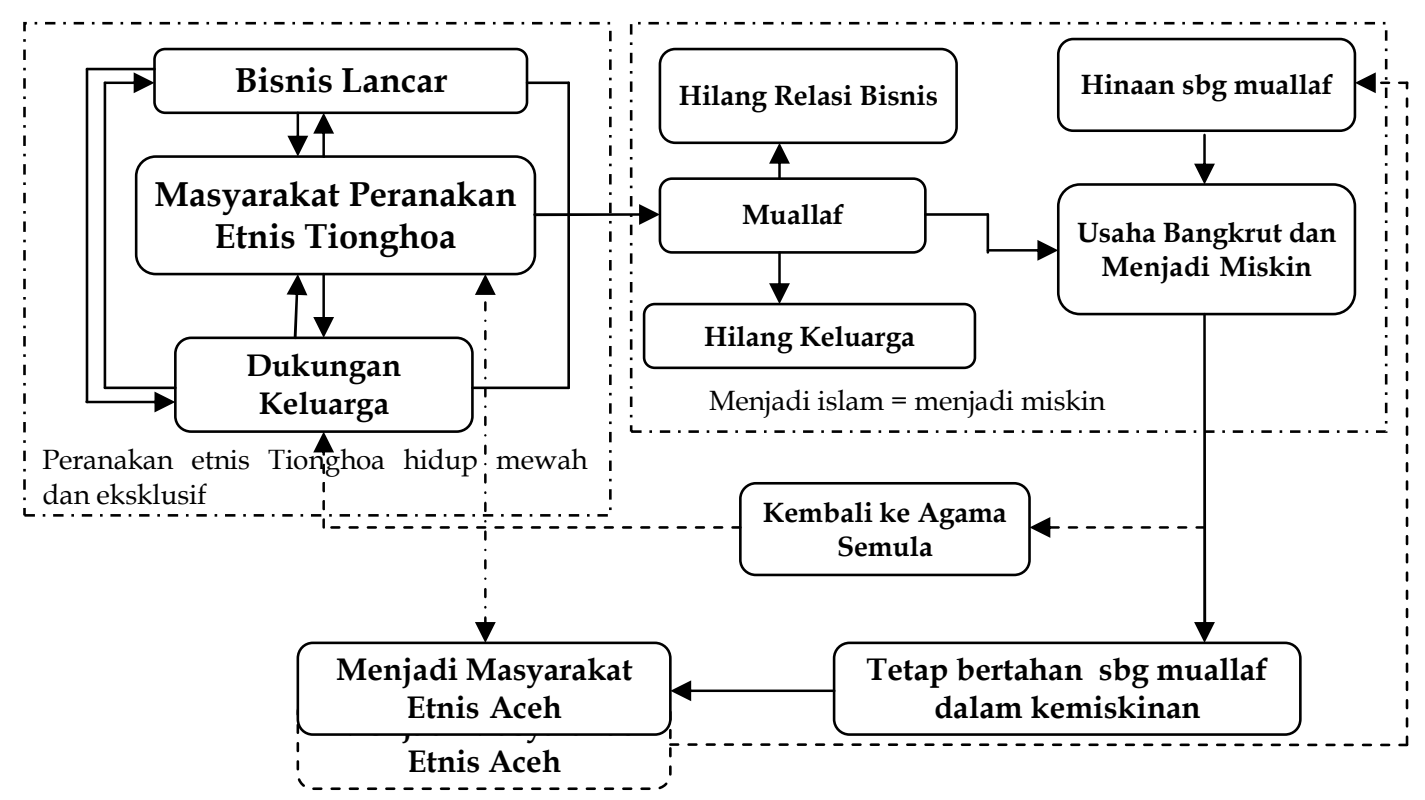

Gambar 1: Model munculnya Menjadi Islam sama dengan menjadi miskin

Bagi peranakan etnis Tionghoa yang tidak tahan dengan hidup miskin, ada kemungkinan kembali ke agama semula. Namun kembali ke agama semula sulit dilakukan di Meulaboh, karena hampir semua peranakan etnis Tionghoa tahu jika seseorang diantaranya telah masuk Islam. Bukan hanya itu, kabar masuknya peranakan etnis Tionghoa ke agama Islam tersebut juga diketahui oleh beberapa orang Aceh khususnya teungku yang memandu pengucapan syahadat, serta beberapa orang yang menjadi saksi, terlebih lagi masyarakat lingkungan masjid tempat pen-syahadatan. Untuk itu peranakan etnis Tionghoa yang telah muallaf jika kembali lagi ke agama semula akan malu, malu terhadap teungku, peranakan etnis Tionghoa dan orang Aceh yang menjadi saksi dan masyarakat Aceh lainnya. Kembali ke agama semula juga dianggap mempermainkan agama dan masyarakat yang telah mendeklarasikan daerahnya sebagai syariat Islam.

Demi menghindari hal itu, kemungkinannya adalah harus keluar dari Meulaboh dan kembali ke agama semula yang sudah ditunggu oleh kelompok atau orang-orang tertentu yang siap memberikan dana bagi kemudahan hidupnya. "Saya ditawarkan uang 50 (lima puluh) juta untuk meninggalkan Islam dan kembali ke agama saya dahulu. Itu keluarga dari ayah saya sendiri", kata Mei. Mei sendiri sudah memiliki keyakinan yang bulat untuk memeluk islam, meskipun hidupnya sangat susah. Hidup sebagai pemulung sampah dan sempat dipercaya untuk menjaga anak seorang dokter kenalannya. Baginya uang sebesar itu akan segera habis, jika dibandingkan dengan keislamannya yang sangat berharga.

Begitu juga dengan beberapa muallaf peranakan etnis Tionghoa lainnya yang bertahan di Meulaboh, hidupnya miskin atau tidak sekaya dengan peranakan lainnya yang memiliki usaha dagang yang besar. Namun hidupnya yang miskin justeru seperti menjadi berkah tersendiri, karena hidupnya yang demikian pada akhirnya masyarakat Aceh yang mengenalnya dengan baik akhirnya menikahi dan akhirnya dapat melebur menjadi orang Aceh. Dimana menjadi "pribumi" merupakan salah satu status yang diidamkan mayoritas peranakan etnis Tionghoa di Indonesia. 
Banyak peranakan etnis Tionghoa yang sesungguhnya ingin juga menjadi orang Aceh seperti etnis Jawa, Padang, Sunda, Batak dan lainnya. Namun, itu tidak mudah jika tidak melebur menjadi satu dengan agama orang Aceh. Meskipun orang Aceh tidak pernah mempersoalkan tentang agamanya, tetapi baginya sangat sulit berinteraksi jika tidak menjadi muslim. Hanya saja ketika menjadi muslim, kehidupan juga lebih pahit dari pada menjadi peranakan etnis Tionghoa biasa. Dalam hal ini Mei banyak bercerita, dan kebanyakan peranakan etnis Tionghoa takut jika harus hidup ditinggalkan relasi bisnis dan keluarga sehingga hidupnya menjadi miskin. Maka muncullah istilah "Menjadi Islam Sama Dengan Menjadi Miskin", apalagi hampir semua muallaf peranakan etnis Tionghoa hidupnya menjadi miskin.

\section{Menjalani Kemiskinan Hidup peranakan etnis Tionghoa di Meulaboh}

Hidup miskin bagi muallaf peranakan etnis Tionghoa seperti sebuah jebakan, dimana jika bersedia kembali ke agama semula akan kembali mendapatkan kehidupannya yang baik. Sedangkan jika tetap menjadi Islam, selamanya akan kehilangan relasi bisnis, dibuang dari keluarga dan belum tentu mendapat tempat dihati masyarakat Aceh. Namun, kembali ke agama semula bisa mendapatkan kembali kehidupan yang nyaman dengan keluarga, dan mendapatkan kembali relasi bisnisnya, tetapi tetap terasa betapa ruginya hidup di dunia karena telah meninggalkan keislamannya. Ada sanksi berat yang juga harus ditanggungnya, yakni kehilangan kepercayaan dari masyarakat Aceh, kehilangan kepercayaan dari teungku yang memandu bersyadat, dan dianggap mempermainkan agama.

Untuk mempertahankan keyakinan barunya, muallaf peranakan etnis Tionghoa harus berjuang melawan kemiskinan dengan cara bekerja keras. Sebagian bekerja sebagai tukang sampah, dimana harus membersihkan sampah di jalanan. Pekerjaan ini tidak biasa dilakukan oleh peranakan etnis Tionghoa pada umumnya di berbagai kota di Indonesia. Demikian halnya di Meulaboh, tidak banyak peranakan etnis Tionghoa yang bekerja sebagai tukang sampah. Sebagai tukang sampah di kota, maka akan mendapatkan upah bulanan dari pemerintah khususnya dinas yang mengelola kebersihan kota.

Kok Eyuk Wun sendiri pernah bekerja sebagai tukang parkir. Beberapa tempat parkir cukup baik untuk dijadikan pendapatan, khususnya tempat-tempat yang mobilitas kendaraannya sangat tinggi seperti pertokoan yang ramai pengunjung. Ramainya pengunjung toko yang parkir, akan semakin banyak uang dihasilkan. Semakin pendek waktu yang diperlukan untuk parkir, maka akan memperbanyak pendapatan, karena kendaraan akan parkir silih berganti. Bukan hanya itu saja, semakin bertambahnya jumlah penduduk juga akan mempengaruhi jasa transportasi atau pengguna kendaraan. Dengan demikian permintaan jasa parkir juga akan semakin bertambah. Kajian Rani Syukriwati et all menunjukkan bahwa permintaan jasa parkir dengan pertumbuhan penduduk berbanding lurus. ${ }^{14}$ Namun pengalaman Kok Eyuk Wun menyatakan bahwa pada tempat-tempat yang sepi pengunjung, juga tidak menjanjikan pendapatan yang baik.

14 Rani Syukriwati dkk. Pengaruh Jumlah Penumpang dan Jumlah Kendaraan Terhadap Pendapatan Jasa Parkir di Bandar Udara Mutiara Sis Al-Jufri Palu. E jurnal katalogis, volume 4 nomor 9, september 2016. Hal. 95-106 
Berbeda dengan Kok Eyuk Wun, Mei menjalani kehidupannya dengan menjadi pengasuh seorang anak. Baginya mengasuh seorang anak merupakan kepercayaan yang luar biasa. Pada jaman sekarang banyak terjadi penculikan anak, artinya siapapun yang berniat jahat bisa menculik anak-anak yang dititipkan kepadanya setiap saat. Maka ketika seseorang telah menitipkan anaknya untuk diasuh, baginya adalah anugrah karena mendapat kepercayaan itu. Sebagai imbalannya, Mei akan mendapatkan upah setiap bulannya walaupun tidak sebanyak peranakan etnis Tionghoa lainnya yang memiliki bisnis dalam toko-toko di kota.

Bagi Tjong Hang, bekerja di tempat pembuatan es batu merupakan pekerjaan yang mampu memperpanjang hidupnya. Dengan bekerja di tempat ini bisa mendapatkan uang untuk membiayai hidup keluarganya. Jika diperhatikan banyak peranakan etnis Tionghoa yang bekerja di sebuah perusahaan. Bahkan pada tahun 2015 sampai dengan 2016 ini banyak berita televisi menyiarkan tentang pekerja asing dari China. Bahkan menteri tenaga kerja Hanif Dhakiri sempat marah ketika sidak di sebuah pertambangan di Kalimantan Selatan. ${ }^{15}$ Pembangkit Listrik Tenaga Uap Suak Puntong di Nagan Raya pada tahun 2014 terlihat orang China bekerja di sana, dan Kok Eyuk Wun sempat menjadi transleter. Kini usia Tjong Hang sudah tua, bahkan juga sudah pensiun sebagai pekerja pabrik es batu. Anak-anaknya yang lebih dahulu masuk Islam, dan sudah menikah semua dengan adat istiadat Aceh turut menopang hidupnya.

Hidup sebagai seorang muslim yang ditinggalkan oleh relasi bisnis dan dibuang keluarga, memang benar-benar susah. Islam sebagai keyakinannya yang baru tidak membolehkan mendendam dengan relasi bisnis dan keluarganya, bahkan harus menjalin silaturahmi. Sebagai makhluk sosial, muallaf peranakan etnis Tionghoa tidak bisa hidup sendirian. Kimball Young dan Raymond, W. Mack mengatakan bahwa interaksi merupakan kunci dari semua kehidupan sosial. ${ }^{16}$ Namun dalam berinteraksi diperlukan sumber-sumber informasi yang sering menyebabkan menyebabkan perbedaan sikap dan perilaku seseorang terhadap orang lainnya. Menurut Karp dan Yoels seperti dikutip Sunarto bahwa sumber-sumber informasi tersebut ialah "ciri fisik yang diwarisi sejak lahir seperti jenis kelamin, usia, dan ras, serta penampilan-daya tarik fisik, bentuk tubuh, penampilan berbusana, dan percakapan" ${ }^{17}$

Sebagai makhluk hidup, bagaimanapun harus bekerja keras baik dengan cara memproduksi, mendistribusikan, dan kemampuan mengelola atau mengatur konsumsi. Sementara itu peralatan dan sejumlah fasilitas untuk memenuhi kebutuhan, tidak tersedia secara merata. ${ }^{18}$ Menghadapi situasi seperti itu, maka antar sesama diperlukan interaksi yang baik agar kebutuhan-kebutuhan hidup dapat terpenuhi, melalui aktivitas saling menolong, saling memberi dan saling menerima.

Berinteraksi dengan masyarakat lokal senantiasa menjadi impian bagi peranakan etnis Tionghoa, namun keinginan tersebut sulit terwujud karena persepsi masing-

\footnotetext{
${ }^{15}$ www.youtube.com Hal. 54

16 Soerjono Soekanto. Sosiologi Suatu Pengantar. PT. RajaGrafindo Persada. Jakarta. 2006.

${ }^{17}$ Kamanto Sunarto. Pengantar Sosiologi. Edisi Revisi. Jakarta. Lembaga Penerbit Fakultas Ekonomi Universitas Indonesia. 2004. Hal. 42

18 Johnson, Doyle Paul. Teori Sosiologi Klasik dan Modern. Alih Bahasa Robert M.Z. Lawang. PT. Gramedia. Jakarta. 1986. Hal. 134
} 
masing. Bagi muallaf peranakan etnis Tionghoa berinteraksi dan mendapat pengakuan sebagai masyarakat daerah tersebut dari masyarakat lokal tidak begitu sulit. Karena setelah menjadi muallaf, menjadi lebih dikenal oleh masyarakat lokal yang mayoritas muslim. Bahkan hidupnya yang miskin memaksa untuk tinggal di tempat-tempat sederhana, sehingga justru mampu berbaur dengan masyarakat lokal. Baqir Zein mengatakan bahwa untuk mudah berbaur dengan masyarakat lokal peranakan etnis Tionghoa akan lebih mudah jika melalui pendekatan agama, artinya peranakan etnis Tionghoa harus menjadi memeluk agama mayoritas. ${ }^{19}$

Bagi sebagian peranakan etnis Tionghoa hidup setelah menjadi muallaf tidak begitu susah, jika dijalani dengan baik. Kemiskinan bagi muallaf merupakan ujian dan cobaan. Sebelum teungku memandu bersyahadat, peranakan etnis Tionghoa yang akan masuk islam diberikan petuah bahwa sebagai seorang muslim akan banyak mengalami ujian seperti tertera dalam Qur'an Surah Ali Imran 186:

"Kamu sungguh-sungguh akan diuji terhadap hartamu dan dirimu. Dan (juga) kamu sungguh-sungguh akan mendengar dari orang-orang yang diberi kitab sebelum kamu dan dari orang-orang yang mempersekutukan Allah, gangguan yang banyak yang menyakitkan hati. Jika kamu bersabar dan bertakwa, maka sesungguhnya yang demikian itu termasuk urusan yang patut diutamakan". (QS: 3. 186)

Dengan demikian maka setiap muallaf peranakan etnis Tionghoa memahami bahwa menjalani hidup sebagai orang Islam akan mendapat ujian berupa kekurangan harta sampai dengan hal yang menyakitkan. Bagi Mei Liza, Chien Mei, Kok Eyuk Wun, Tjong Hang dan beberapa lainnya sudah mengalami cobaan-cobaan itu. Pahit dan menyakitkan, namun bagi komunitasnya (Ikatan Keluarga Muallaf yang disingkat IKM) menganggap keyakinan barunya lebih berharga dari harta benda yang hanya berlaku di dunia yang sesaat. Hidup dalam kemiskinan akan tetap dijalaninya sampai sejauh kemampuannya hingga Tuhan memanggilnya.

\section{PENUTUP}

Munculnya ungkapan "menjadi islam sama dengan menjadi miskin" di kalangan peranakan etnis Tionghoa diawali karena adanya beberapa peranakan etnis Tionghoa di Meulaboh yang menjadi islam dan meninggalkan agama asalnya. Menjadi islam, dianggap juga meninggalkan adat istiadat dan budaya nenek moyangnya. Bukan hanya sekedar meninggalkan budaya saja, karena meninggalkan budaya juga dianggap melupakan nenek moyangnya. Untuk itu, peranakan etnis Tionghoa yang non muslim akan meninggalkan dan memutuskan hubungan bisnis dengan peranakan etnis Tionghoa muallaf. Dengan diputuskan hubungan bisnis, maka muallaf peranakan etnis Tionghoa akan merugi dan bangkrut. Diusir dari keluarga memperparah kehidupan ekonominya, maka kemudian muallaf peranakan etnis Tionghoa hidupnya menjadi miskin. Bahkan ketika sudah menjadi muallaf beberapa orang Aceh juga mencemooh dan menuduh muallaf peranakan etnis Tionghoa bahwa ketika sudah miskin baru menjadi islam, atau kalau punya kemauan menjadi muallaf mengapa tidak sejak masih kaya. Dengan kondisi seperti ini, akhirnya kebanyakan

19 Abdul Baqir Zein. Etnis Cina dalam Potret Pembauran di Indonesia. Prestasi Insan Indonesia. Jakarta. 2000. Hal. 93-98. 
peranakan etnis Tionghoa lainnya yang akan masuk islam menjadi takut. Takut kehilangan keluarga, teman dan rekan bisnis, juga takut menjadi miskin. Maka muncullah ungkapan "menjadi islam sama dengan menjadi miskin".

Sementara itu muallaf peranakan etnis Tionghoa yang tetap bertahan di Kota meulaboh, terpaksa harus bekerja keras dengan menekuni berbagai macam pekerjaan yang tidak biasanya dilakukan peranakan etnis Tionghoa pada umumnya. Hidup miskin bukan hanya menimpa pada orang islam saja, berbagai umat beragama juga mengalami hidup miskin. Ada keyakinan bahwa siapa saja yang mau bekerja keras akan mendapatkan rejeki yang baik dari Tuhan. Selain itu, hidup miskin bukan hal yang dibenci Tuhan, bahkan dalam hadist nabi disebutkan bahwa: "Aku berdiri di depan pintu surga, maka (kulihat) mayoritas orang yang memasukinya adalah orangorang miskin".(HR. Bukhori:6547, Muslim: 2736). Meski demikian, usaha untuk meningkatkan penghasilan selalu dilakukan, sehingga kerja keras bahkan pekerjaan yang dianggap kerja kasar juga dilakukan. Sebagian muallaf peranakan etnis Tionghoa bekerja sebagai pekerja seperti penjual buku, penjaga anak, tukang parkir, tukang kebersihan, bahkan pemulung. Dengan bekerja keras muallaf peranakan etnis Tionghoa mendapatkan rejeki untuk kehidupannya.

\section{Referensi}

A. Rani Usman. 2009. Etnis Cina Perantauan di Aceh. Yayasan Obor Indonesia. Jakarta.

Triyanto. 2014. Dakwah Islam pada Komunitas Tionghoa (Studi Tentang Adaptasi Dengan Masyarakat di Meulaboh Kabupaten Aceh Barat). UIN Ar-raniry. Banda Aceh.

Justian Suhandinata, 2009. WNI Keturunan Tionghoa dalam Stabilitas Ekonomi \& Politik Inndonesia, Jakarta: Gramedia Pustaka Utama.

Irma saragih. 2013. Analisis Dampak Program Raskin Terhadap Kesejahteraan Rumah Tangga Miskin: Studi Kasus di Gampong Ujong Tanoh Darat Kecamatan Meurebo Kabupaten Aceh Barat. Prodi Administrasi Negara Fisip Universitas Teuku Umar Meulaboh.

Rani Syukriwati dkk. 2016. Pengaruh Jumlah Penumpang dan Jumlah Kendaraan Terhadap Pendapatan Jasa Parkir di Bandar Udara Mutiara Sis Al-Jufri Palu. E jurnal katalogis, volume 4 nomor 9, september 2016. Hal. 95-106

Dhea Putri Herdiningrum, Adaptasi Kelompok Muallaf Tionghoa di Kecamatan Pontianak Kota, http://jurnalmahasiswa.fisip.untan.ac.id.

Eddie Kusuma dan S. Satya Dharma. 2006. Etnis Tionghoa Dalam Politik Indonesia Sebelum dan Sesudah Reformasi 1998, Jakarta: Suara Kebangsaan Tionghoa Indonesia (SAKTI) dan Asosiasi Wartawan Muslim (AWAM) Indonesia.

Soerjono Soekanto. 2006. Sosiologi Suatu Pengantar. PT. RajaGrafindo Persada. Jakarta.

Kamanto Sunarto. 2004. Pengantar Sosiologi. Edisi Revisi. Jakarta. Lembaga Penerbit Fakultas Ekonomi Universitas Indonesia. 
Community: volume 2, nomor 2, April 2016

ISSN: 2477-5746

Abdul Baqir Zein. 2000. Etnis Cina dalam Potret Pembauran di Indonesia. Prestasi Insan Indonesia. Jakarta.

Johnson, Doyle Paul. 1986. Teori Sosiologi Klasik dan Modern. Alih Bahasa Robert M.Z. Lawang. PT. Gramedia. Jakarta.

www.youtube.com 